\title{
Water Quality Assessment of Carangan Estero in Ozamiz City, Philippines
}

\author{
Marie Rosellynn C. Enguito, Victoria E. Matunog, Jessie Jane O. Bala, \\ Yunalyn L. Villantes
}

\author{
Natural Science Department, College of Arts and Sciences, Misamis University, \\ Ozamiz City, Philippines \\ Corresponding email: roselle_8888@yahoo.com
}

\begin{abstract}
Water quality in Esteros is deteriorating due to pollution influx from various human activities. The water quality of Carangan Estero in Ozamiz City was assessed by conducting the physicochemical and bacteriological analyses of water samples. Water sampling from May to June 2013 was done upstream in Barangay Calabayan (Site 1), midstream in Barangay Lam-an (Site 2) and downstream in Barangay San Roque (Site 3). Results showed an increasing temperature downstream that was within the Department of Environment and Natural Resources standards for Class $\mathrm{C}$ waters. The low $\mathrm{pH}$ in Sites 1 and 2 that ranged from 6.0 to 6.3 did not fall within the standard which could be attributed to the presence of dam and quarry activity upstream and influx of organic wastes midstream. Dissolved oxygen was decreasing downstream and the lowest reading of $2.9 \mathrm{mg} / \mathrm{L}$ was below the minimum limit. Biological oxygen demand of $7.2 \mathrm{mg} / \mathrm{L}$ in Site 3 exceeded the maximum standard. Total alkalinity in all sites was below the typical level for fresh water and was limited to bicarbonate ions only. Total hardness was increasing downstream. Phosphate concentration did not exceed the standard. Fecal coliform count increased downstream ranging from 4600 to $>11,000 \mathrm{MPN} / 100 \mathrm{~mL}$ that exceeded the standard limit. Overall assessment revealed that water quality was deteriorating downstream due to relatively high discharge of organic waste from toilets, kitchen, piggeries, laundry and commercial establishments associated with dense population. A collaborative and sustainable effort of the community is necessary to restore water quality.
\end{abstract}

Keywords: Biological oxygen demand, coliform, $\mathrm{pH}$, phosphate, total alkalinity 


\section{Introduction}

Water quality in urban streams is deteriorating to an alarming extent (Orozco \& Zafaralla, 2012; Martinez \& Galera, 2011; Teresa et al., 2011; Langhammer, 2010). At the global scale, hydrologic modifications have detrimental consequences to aquatic environment and human health (Naiman \& Dudgeon, 2011; O'Toole et al., 2009).

Alterations in the physicochemical and biological characteristics due to water pollution affect the quality of the stream environment resulting to reduced life support functions that this ecosystem provides (Venkatesharaju et al., 2010). Water pollution can introduce microorganisms (Odeyemi et al., 2011; Tarkan, 2010; Emeka et al., 2009) which lead to increased human morbidity and mortality resulting from water-borne diseases (Govender et al., 2011).

Anthropogenic modifications of the conditions of river channels are the most widespread and potent threats to water quality. Rapid urbanization increases the point source and non-point source pollution in water (Juahir et al., 2011). Indiscriminate dumping of solid wastes and effluents into streams alters the physicochemical properties of water making it not suitable for human consumption (Islam et al., 2012). Organic pollution in rivers and streams of developing countries is in dreadful condition compared to developed countries (Sikder et al., 2013). In the Philippines, environmental degradation of river and stream ecosystem places the country among the most threatened (Fernandez, 2009).

Esteros are urban streams or creeks that are heavily polluted from various human activities (Orozco \& Zafaralla, 2012). Waste from domestic sources, agriculture, commercial establishments and industries alter the physicochemical parameters of water in major Philippine esteros, that do not meet the national standards for drinking and for aquaculture (PEMSEA, DENR and LLDA, 2013; Orozco \& Zafaralla, 2012; Gorme, et al., 2010; Rañola \& Santiago, 2009), despite the efforts of the government to improve water quality. Poor water quality resulting from pollution reduces environmental heterogeneity which leads to low diversity of aquatic life (Teresa et al., 2011). 
The massive pollution in esteros can be related to the frequent occurrence of flood-related disasters in highly urbanized areas in the Philippines (Gilbuena et al., 2013) as wastes impede water flow during flooding making the country one of the flood prone countries in the world (Gaillard et al., 2008). With the impact of climate change at present time, water pollution is reaching a critical state in developing countries as human health is also at great risk (Smith, 2007). Increased human settlements along esteros are exacerbating water pollution by exposing the streams to contamination from untreated sewage going directly into the water.

Esteros in Ozamiz City emanate from river systems in Mt. Malindang which supply potable water to lowland areas for domestic and agricultural uses. However, in urban areas, esteros become the dumping sites of waste from various sources. The present condition of these esteros could possibly pose a threat to the water quality in Panguil Bay, a small body of water that serves as the fishing ground of thousands of small-scale fishers in northwestern Mindanao due to its high biodiversity (Jimenez et al., 2009). In the recent study of Canini et al. (2013), the changes in nutrients and other physico-chemical parameters have influenced the phytoplankton abundance in Panguil Bay. The dumping of wastes into esteros could also pose a hazard to the inhabitants mostly those living along the esteros as massive flooding also occurs in Ozamiz City (Alipa \& Rosauro, 2012).

In order to address the present conditions of esteros in Ozamiz City, the "Adopt-an-Estero Program" has been undertaken by the local government in collaboration with the estero community, private sectors and academic institutions. This program was launched nationwide by the Department of Environment and Natural Resources (DENR) in 2010 towards a common direction of rehabilitating and protecting the environment from massive water pollution (DENREMB, 2010). However, the continuous dumping of considerable amount of wastes from household and commercial establishments can still pose a threat to the water quality in esteros of Ozamiz City despite extensive clean-ups initiated by the academic community. With the growing human population living along esteros, there is a need for information on the water quality and the threats to this aquatic environment as basis to establish effective conservation and management strategies. At present, there is insufficient information on 
the water quality of esteros. This study assessed the water quality of Carangan Estero in Ozamiz City by conducting the physicochemical and bacterial analysis of water.

\section{Materials and Methods}

\section{Sampling sites}

This study was conducted along Carangan Estero in Ozamiz City (Figure 1). The Estero was divided into three sections, namely: upstream in Site 1, Barangay Calabayan (123 ${ }^{\circ} 48.530^{\prime}$ East; 08 $8^{0} 10.028^{\prime}$ North), midstream in Site 2, Barangay Lam-an ( $123^{\circ} 50.342^{\prime}$ East; $08^{0}$ $09.016^{\prime}$ North), and downstream in Site 3, Barangay San Roque $\left(123^{0}\right.$ 50.484' East; $08^{0} 08.570$ North'). Site 1 was situated below a dam that runs along an agricultural field at an elevation of 70 meters above sea level (masl) which was characterized by patchy vegetation and few houses at a far distance. Site 2 was situated at 3,810 meters from Site 1 at an elevation of 29 masl which was characterized by numerous houses built along. House renting and hog-raising were the main income-generating activities in Site 2. Site 3 was situated in the center of the city near a public market at an elevation of 20 masl and was 635 meters away from Site 2 which was characterized by commercial establishments and many houses built along the banks. The water in Site 3 drains into the Panguil Bay.

\section{Physicochemical measurements}

Surface water samples were collected in triplicates into sterile bottles and transported to the laboratory in a cooler for analysis of other parameters not determined in situ. Bottles were rinsed three times with stream water before the collection for laboratory analysis. Bottles were sealed and labelled with the sampling source and date of collection. Water sampling was done from May to June, 2013. Stream velocity, temperature, $\mathrm{pH}$, dissolved oxygen (DO), Biological Oxygen Demand (BOD), total alkalinity, total hardness, and phosphate concentration were the physicochemical parameters determined in situ or analyzed in the laboratory. 


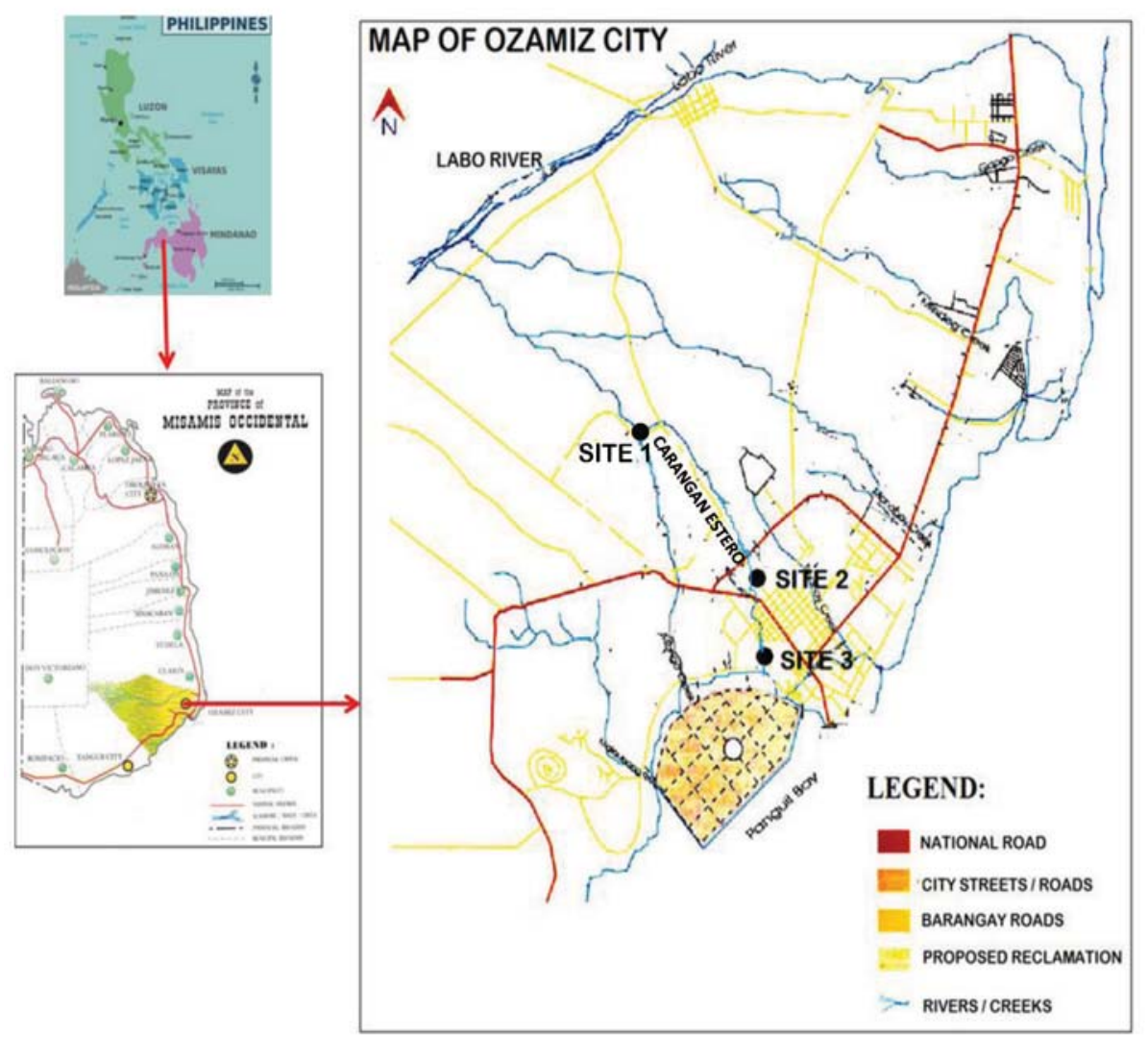

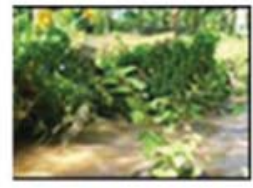

Site 1- Brgy. Calabayan

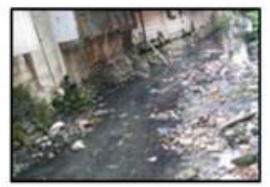

Site 2- Brgy. Lam-an Site 3- Brgy. San Roque

Figure 1. Location Map with pictures showing the sampling sites along Carangan Estero in Ozamiz City.

The float method determined the stream velocity. A portable $\mathrm{pH}$ meter measured on site the $\mathrm{pH}$ of water. The Dissolved Oxygen Meter-EXPECH instrument that measured the DO also read the temperature at the site. The Winkler Method (BBSR, 1997) conducted in the laboratory verified the DO reading taken in situ. In this study, the standardization of sodium thiosulfate used potassium dichromate 
instead of potassium iodate. Bottle incubation of diluted water samples for 3 days at $27^{\circ} \mathrm{C}$ was used to determine the BOD (HPTM, 1999). The unseeded dilution water diluted the water sample to $25 \%$ concentration. The sample in $\mathrm{DO}_{0}$ bottle was analyzed for the initial DO concentration while the sample in $\mathrm{DO}_{3}$ bottle was incubated at $27^{\circ} \mathrm{C}$ and analyzed on day 3. BOD is the difference of $\mathrm{DO}_{0}$ and $\mathrm{DO}_{3}$. Method was modified as to the incubation period of samples because the pretrial done for water analysis showed that dissolved oxygen in water samples, using $100 \%$ concentration, was all consumed before day $5 . \mathrm{BOD}_{3}$ at $27^{\circ} \mathrm{C}$ is comparable to $\mathrm{BOD}_{5}$ at $20^{\circ} \mathrm{C}$ (HPTM, 2002). The EDTA Tritrimetric method determined the total hardness (APHA, 1998) while titrimetric to $\mathrm{ph}=4.5$ (methyl orange) determined the total alkalinity (HPTM, 1999). Stannous chloride method determined the phosphate concentration (APHA, 1998).

\section{Bacterial analysis}

The standard bacterial water analysis (AWWA, 1993) performed in the laboratory using aseptic technique determined the coliform count in samples expressed in most probable number per 100 $\mathrm{mL}$ (MPN/100 mL). Presumptive, confirmatory and completed tests were done. In presumptive test, a series of lactose broth tubes were inoculated with water sample for three serial tube dilutions. All tubes were incubated at $37^{0} \mathrm{C}$ for 48 hours. Gas production in tubes indicated positive result for the presence of coliforms. In confirmatory test, the sample from positive presumptive tubes was streaked on Eosin Methylene Blue (EMB) agar plates. The plates were inverted and incubated at $37^{\circ} \mathrm{C}$ for 48 hours. Small colonies with dark centers and a green metallic sheen indicated a positive confirmed test for the presence of E. coli. In completed test, the brilliant green bile broth tubes were inoculated with materials from EMB plates and incubated at $37^{0} \mathrm{C}$ for 48 hours. Gas production in broth tubes indicated a positive result. The most probable number (MPN) of fecal coliforms in $100 \mathrm{ml}$ water sample was estimated by the number of positive tubes using the MPN Table. 


\section{Results and Discussion}

\section{Physicochemical measurements}

Poor water quality resulting from pollution reduces environmental heterogeneity which leads to low diversity of aquatic life (Teresa et al., 2011). Table 1 shows the standard values (DENR limit) and the obtained values of physico-chemical properties of water measured for each sampling site. Water is vital to life, hence, looking into the interplay between abiotic and biotic factors is important. Patterns yield proved to be useful in addressing and understanding the present conditions. Figure 2 shows the physico-chemical parameters measured for the three sampling sites. It was found out that temperature increased downstream with values $\left(28.2^{0} \mathrm{C}\right.$ to $\left.29.4^{0} \mathrm{C}\right)$ that fall within the $25^{\circ} \mathrm{C}$ to $31^{\circ} \mathrm{C}$ DENR standards for Class $\mathrm{C}$ waters. Water in this classification is used only for fishery, boating, agriculture, irrigation and livestock watering and is not safe for human consumption (DAO, 2008). This is not similar with the water quality in Estero de San Miguel and Estero de Quiapo in Manila which falls in the lowest Class D classification (Orozco \& Zafaralla, 2012).

Table 1. Physico-chemical properties of water in three sites and DENR limit for Class $\mathbf{C}$ waters.

\begin{tabular}{|c|c|c|c|c|}
\hline Parameter & $\begin{array}{c}\text { Site } 1 \\
\text { (Brgy. } \\
\text { Calabayan) }\end{array}$ & $\begin{array}{c}\text { Site } 2 \\
\text { (Brgy. } \\
\text { Lam-an) }\end{array}$ & $\begin{array}{c}\text { Site } 3 \\
\text { (Brgy. San } \\
\text { Roque) }\end{array}$ & $\begin{array}{c}\text { DENR } \\
\text { limit } \\
\text { Class C }\end{array}$ \\
\hline Stream velocity & $9.1 \mathrm{~cm} / \mathrm{sec}$ & $33.0 \mathrm{~cm} / \mathrm{sec}$ & $21.7 \mathrm{~cm} / \mathrm{sec}$ & - \\
\hline Temperature $\left({ }^{\circ} \mathrm{C}\right)$ & 28.2 & 28.7 & 29.4 & $25-31$ \\
\hline $\mathrm{pH}$ & 6.0 & 6.3 & 7.0 & $6.5-9.0$ \\
\hline Dissolved oxygen (DO) (mg/L) & 13.2 & 7.4 & 2.9 & 5 \\
\hline Biological oxygen demand $\left(\mathrm{BOD}_{3}\right)(\mathrm{mg} / \mathrm{L})$ & 3.9 & 4.0 & 7.2 & 7 \\
\hline Total alkalinity $\left(\mathrm{mg} / \mathrm{L} \mathrm{CaCO}_{3}\right)$ & 8.6 & 11.6 & 16.7 & - \\
\hline Total hardness $\left(\mathrm{mg} / \mathrm{L} \mathrm{CaCO}_{3}\right)$ & 55.1 & 78.5 & 90.1 & - \\
\hline Phosphate $(\mathrm{mg} / \mathrm{L})$ & 0.18 & 0.18 & 0.40 & 0.5 \\
\hline
\end{tabular}



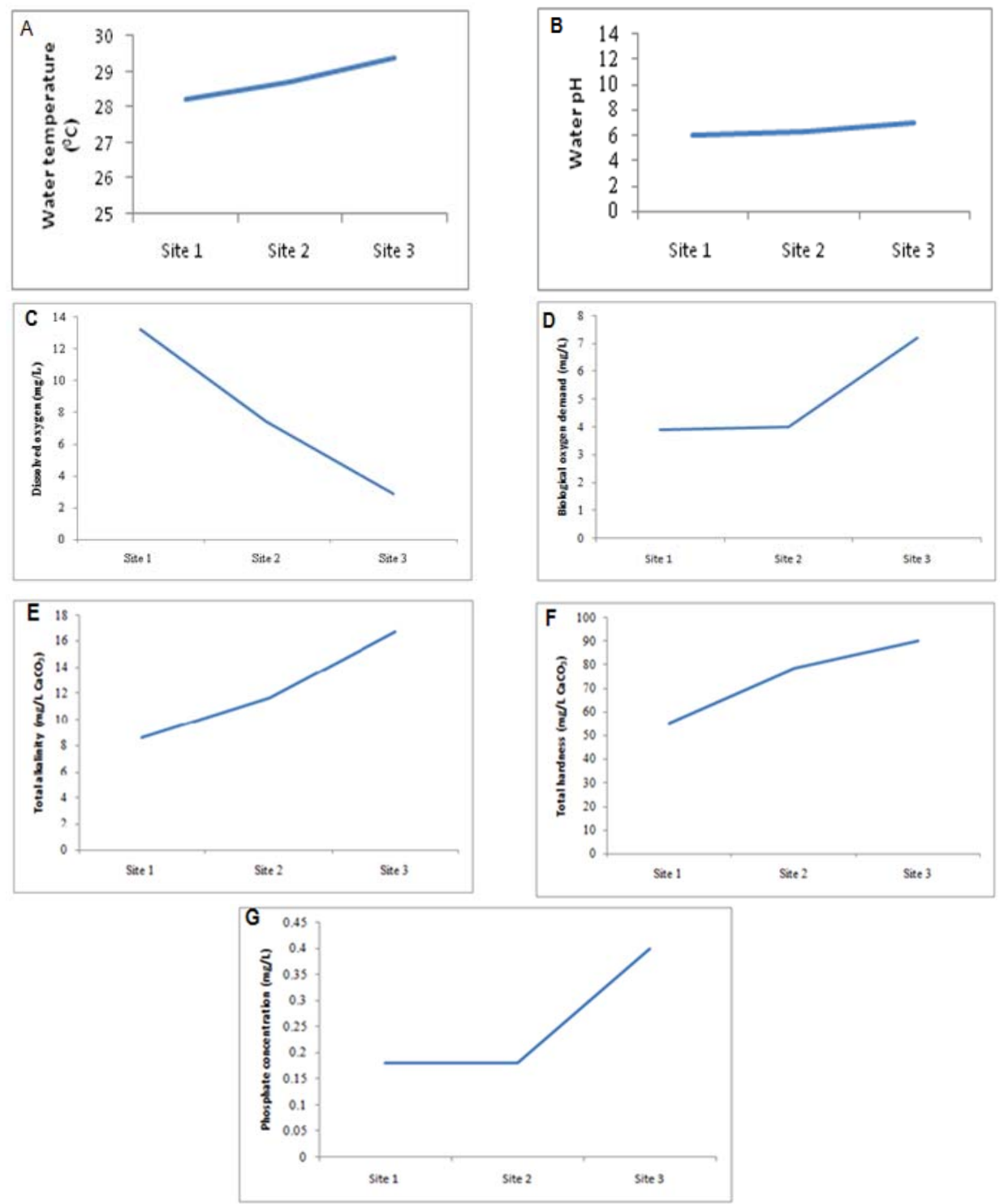

Figure 2. Physico-chemical parameters of water: A.) Temperature; B.) pH; C) DO; D) BOD; E) Total alkalinity; F) Total hardness; and G) Phosphate concentration. 
The patchy vegetation in Site 1 at a higher elevation (63 masl) partly blocks sunlight. Moderately dense vegetation protects the water from extreme heating and cooling (Borlongan et al., 2010). The houses along opposite sides of the bank in Site 2 partly block sunlight but the low water level $(18.3 \mathrm{~cm}$ depth) contributes to relative temperature increase similar to the findings of water quality analysis in a reservoir in India (Thirupathaiah et al., 2012). The location of Site 3 within the city proper at 20 masl elevation with no shaded areas directly exposes the water to sunlight. Moreover, the muddy water downstream as a result of continuous discharge of effluents may tend to absorb more heat from the sun. Temperature is a critical parameter as aquatic organisms are dependent on certain temperature ranges. Increased temperature is also associated with harmful algal bloom (Moore et al., 2010).

The mean $\mathrm{pH}$ values ranged from acidic to neutral (6.00 to 7.00). Water $\mathrm{pH}$ in Sites 1 and 2 did not fall within the range of 6.5 to 9.0 for Class $\mathrm{C}$ waters. Water from the dam that was drained into Site 1 may contribute to low $\mathrm{pH}$. Impounded water in the dam may become acidic due to the carbon dioxide produced by bacteria decomposing the aquatic plants and algae that die due to low nutrients (Sundberg et al., 2013). Reduced amount of nutrients is the result of decreased stream velocity and nutrient transport due to the presence of dam (Supit \& Ohgushi, 2012). Animal waste and occasional human feces on the banks washed into water during rainy days may contribute to the low $\mathrm{pH}$. The lowest stream velocity of $9.1 \mathrm{~cm} / \mathrm{sec}$ in Site 1 may retain longer acidic water from the dam or from decaying aquatic organisms on the site that die due to low nutrients. Quarry activity few kilometers upstream may also contribute to low $\mathrm{pH}$ due to excavation of limestone. Quarry in the Philippines increases over the years and causes extensive water pollution (EMB, 2005), flooding (Esguerra et al., 2008), and landslides (Martinez et al., 2011).

The influx of organic wastes from toilets, kitchen and piggeries in Site 2 contributes to low $\mathrm{pH}$. Agricultural runoff from Site 1 could also contribute the low $\mathrm{pH}$ in Site 2. Davis and Davis (2011) revealed that decrease in $\mathrm{pH}$ was consistent with an increase in dissolved organics in runoff. 
The $\mathrm{pH}$ value determines the solubility and biological availability of chemicals in water (Omuku et al., 2012). The acidic condition is indicative of stressful conditions to fishes (Orozco \& Zafaralla, 2012) which are used as indicators of stream pollution (Teresa et al., 2011). The low $\mathrm{pH}$ can be detrimental as metals become more soluble (Omuku et al., 2012; Martinez et al., 2011) causing fish toxicity (Martinez et al., 2011; Custer et al., 2006) and reduced survival rate (Crafford \& Oldewage, 2011). Guppies or 'pait-pait' (Poecilia reticulata) and catfish or 'pantat' (Clarias batrachus) observed in Site 1 and the janitor fish, Hypostomus plecostomus and few guppies in Site 2 were highly tolerant to adverse water conditions.

Organic pollution in Site 3 was also massive, but water contamination with detergents could possibly raise the low $\mathrm{pH}$ to neutral. Results imply that water in the three sites is susceptible to changes in $\mathrm{pH}$ which is the result of low and limited buffering capacity or alkalinity. Since water was poorly buffered at the influx of acids or bases, continuous detergent contamination in Site 3 could eventually lead to unfavorable high alkalinity level and may alter other parameters detrimental to water quality. Some residents had pipelines from open laundry and bathing area and jetmatic pump that drained the wash water directly into the estero. Goel and Kaur (2012) revealed that powdered detergents increased the $\mathrm{pH}$ of wash water.

In this study, DO decreased in a downstream direction. The lowest DO reading of $2.9 \mathrm{mg} / \mathrm{L}$ in Site 3 is below the DENR minimum standard of $5 \mathrm{mg} / \mathrm{L}$ for Class $\mathrm{C}$ waters. Organic wastes from toilets, kitchen, piggeries and public market contribute to low DO. Indiscriminate dumping of solid waste such as sanitary napkins, diapers, woods and bodies of dogs, pigs, rats and chicken aggravates organic pollution. This situation escalates with increasing human population downstream which is the same problem encountered in other urban areas in the country (Orozco \& Zafaralla, 2012). Bacteria use oxygen during the breakdown of these organic wastes resulting to low DO level (Orozco \& Zafaralla, 2012; Olaguer et al., 2010). The murky and foul odor water could be the result of influx of the enormous amount of wastewater and sewage from domestic and commercial sources that are acted upon by bacteria. River sediments become black, and the odor is foul in the area with the lowest DO (Borlongon et al., 2010). 
Studies of esteros or rivers in the Philippines showed lower DO readings downstream compared to upstream can be a result of massive discharge of domestic and industrial wastes associated with rapid urbanization (Orozco \& Zafaralla, 2012; Flores \& Zafaralla, 2012; Martinez et al., 2011; Gorme et al., 2010). The hypertrophic water condition resulting from organic wastes causes the fish communities in Estero de San Miguel and Estero de Quiapo in Manila to exhibit high evenness but low in dominance and diversity (Orozco \& Zafaralla, 2012). Species tolerant to adverse condition may replace those intolerant reducing aquatic biodiversity. Only the mudfish, Channa striata, locally called as 'haluan', janitor fish and guppy were observed to inhabit the brackish, stagnant and muddy water in Site 3 with low DO.

The relative high temperature can also contribute to low DO as solubility of oxygen decreases with increasing temperature (Del Mundo \& Rebancos, 2008). The DO upstream and midstream is declining but the values are above the minimum limit. The amount of organic waste in two sites is lesser compared to Site 3. Lesser bacteria are present and thus, DO is higher, and BOD is lower. The DO in Site 2 is lower than in Site 1 due to less amount of organic waste available for bacteria, as the rapid water current can carry the materials downstream. The shallow water in Site 2 may also allow more atmospheric oxygen to dissolve in water resulting to more amount of DO relative to Site 3 .

The BOD increased downstream. Only the value $(7.2 \mathrm{mg} / \mathrm{L})$ in Site 3 exceeds the maximum DENR standard of $7 \mathrm{mg} / \mathrm{L}$ for Class $\mathrm{C}$ waters. The result indicates a huge quantity of aerobic bacteria that use oxygen to degrade the organic wastes. The lowest DO reading could be the result of oxygen uptake by aerobic aquatic bacteria that decompose the organic waste. The continuous dumping of a large quantity of organic waste from households along the estero, could be the primary cause of increased bacterial population. The proximity of the area to the wet public market also contributes to organic pollution. Human and animal feces, banana peelings, diapers, sanitary napkins, dead animal bodies were dumped directly into the water. Effluents from commercial establishments flowed directly into the water through a huge water culvert which produced foul odor. The lesser amount of organic waste can lower the BOD. Fewer bacteria are present to 
decompose the waste, and the demand for dissolved oxygen is low. Site 2 was polluted with massive organic waste, but the rapid stream velocity could carry these materials downstream thus the available nutrient for bacteria was lesser resulting to lower BOD as oxygen demand was lower. Organic wastes increase BOD loading in Metro Manila, Philippines which does not conform to the DENR standard (Orozco \& Zafaralla, 2012; Gorme et al., 2010).

Alkalinity is the buffering capacity of a water body (Borlongan et al., 2010). Measuring alkalinity determines the ability of water to neutralize acids and bases thereby maintaining a fairly stable $\mathrm{pH}$. Carbonate, bicarbonate and hydroxide ions which combine with hydrogen ions cause this buffering capacity (EPA, 2012). Leached from limestone rocks are common sources of carbonates and bicarbonates. In natural waters, carbonate alkalinity tends to make up most of the total alkalinity (Dubois et al., 2010).

Total alkalinity varied and increased downstream with 16.7 $\mathrm{mg} / \mathrm{L}$ as the highest value and $8.6 \mathrm{mg} / \mathrm{L}$ as the lowest. Since alkalinity varies considerably due to differences in geology, there are no general standards for alkalinity. Alkalinity level of $20-200 \mathrm{mg} / \mathrm{L}$ is typical of freshwater. Total alkalinity of $100-200 \mathrm{mg} / \mathrm{L}$ stabilizes the $\mathrm{pH}$ level. Alkalinity level below $10 \mathrm{mg} / \mathrm{L}$ indicates that the water is poorly buffered and is very susceptible to changes in $\mathrm{pH}$ from natural and human-caused sources (BASIN, 2007). In this study, total alkalinity in all sites was below the typical level for fresh water. The buffering capacity of water in Site 3 was poor because the level was below 10 $\mathrm{mg} / \mathrm{L}$.

In the Philippines, assessment of rivers also shows the variation in the buffering capacity of water. In one area in Layawan River with the lowest $\mathrm{pH}$, alkalinity was lowest at $48 \mathrm{ppm}$. However, this buffering capacity maintains the $\mathrm{pH}$ of water within the DENR standards for Class AA waters (Hansel et al., 2006). Alkalinity in Jalaur River system in Iloilo exceeds $100 \mathrm{mg} / \mathrm{L}$ and the $\mathrm{pH}$ values are within the recommended standards (Borlongan et al., 2010).

Results showed that alkalinity of water in three sites were

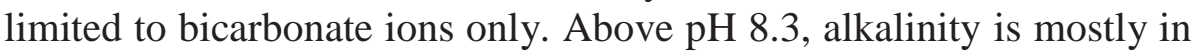
the form of carbonate; below 8.3, alkalinity is present mostly as bicarbonate (BASIN, 2007). This holds true in this study since the $\mathrm{pH}$ values in all sites are below $8.3 \mathrm{mg} / \mathrm{L}$. Thus, the low $\mathrm{pH}$ in Sites 2 
and 3 could also be attributed to the low and limited buffering capacity of water. As increasing amounts of acid are added to water, the $\mathrm{pH}$ of water decreases, and the buffering capacity of the water is consumed (BASIN, 2007). In other developing countries such as in Nigeria with increasing urbanization, reduced alkalinity is caused by the influx of domestic and industrial wastes that are not treated when dumped into rivers due to lack of adequate technology and resources for the treatment (Osibanjo et al., 2011). In Ozamiz City, there is no water treatment available for domestic and commercial organic waste. Low alkalinity value of $8.6 \mathrm{mg} / \mathrm{L}$ in Site 1 could be due to the quarrying of limestone in bedrocks, agricultural run-off and the influx of contaminated water from the dam.

The main polyvalent cations analyzed for water hardness were calcium and magnesium expressed in $\mathrm{mg} / \mathrm{L}$. Since hardness varies greatly due to differences in geology, there are no general standards for water hardness. Waters with total hardness in the range of 0 to 60 $\mathrm{mg} / \mathrm{L}$ are termed soft; from 60 to $120 \mathrm{mg} / \mathrm{L}$ moderately hard; from 120 to $180 \mathrm{mg} / \mathrm{L}$ hard (BASIN, 2007; Hansel et al., 2006). Site 1 is considered as soft water while the other two sites are considered as hard water. Results showed that values were increasing downstream. The slightly acidic water upstream (Site 1) could have dissolved more calcium carbonates from limestones (Qian et al., 2013) but quarry activities in the area may have removed the limestones thereby decreasing the hardness in water. Downstream, the increased hardness indicates more sewage outflow from domestic and commercial sources as observed in this study. High hardness values in Site 2 and Site 3 may be attributed to the household wastewater that contains calcium and magnesium from cleaning agents, food residue, and human waste. However, stream velocity was rapid midstream, which may cause these wastes to drift downstream, reducing the relative hardness in Site 2. Total hardness in three sites is low compared to the results of other studies in less polluted rivers and reservoir (Thirupathaiah et al., 2012; Borlongon et al., 2010; Hansel et al., 2006). Although hardness also affects aquatic life by mitigating metals toxicity (Linbo et al., 2009), unregulated increase in level due to increase sewage outflow may have a negative impact on the stream ecosystem.

Phosphate concentration ranging from 0.18 to $0.40 \mathrm{mg} / \mathrm{L}$ in three sites did not exceed the DENR limit of $0.5 \mathrm{mg} / \mathrm{L}$ for Class $\mathrm{C}$ 
waters. Laundry detergents from washing and bathing activities of residents in the dam, below the dam and runoff from agriculture and human feces along the banks could be the possible sources of phosphate in Site 1.

Domestic sewage and animal wastes increase the concentration of phosphate ions in water (Juahir et al., 2011; Tarkan, 2010). House renting and hog-raising were the main income-generating activities in Site 2 which may cause massive and direct input of various types of waste including laundry and kitchen waste, human excreta and piggery wastes. However, the phosphate concentration was lower compared to Site 3 and BOD and DO readings were within the DENR standards. Stream velocity was rapid midstream $(33.0 \mathrm{~cm} / \mathrm{sec})$, causing the wastes to drift downstream, reducing the amount of phosphate in Site 2.

Wastewater contamination from laundry detergents and high discharge of sewage from toilets, piggeries, kitchen and wet public market may contribute to the highest phosphate concentration in Site 3. Increase phosphate concentration contributes to hypertrophication and subsequent decrease in water quality (Cunha et al., 2011; Juahir et al., 2011; Borlongon et al., 2010; Morgan et al., 2006). Phosphates are plant nutrients that can cause plants and algae to grow quickly in excess but also die quickly. Thus, nutrient enrichment can also increase bacterial load in water resulting to high BOD, and low DO (Martinez \& Galera, 2011). There is a high fecal bacteria load and periodic algal bloom from nutrient loading in suburban creeks (Mallin et al., 2012). Site 3 was highest in phosphate level, highest in BOD and lowest in DO readings.

\section{Bacteriological Assessment}

Table 2 shows that the fecal coliform count increases downstream with values (from 4600 to $>11,000 \mathrm{MPN} / 100 \mathrm{~mL}$ ) that exceed the DENR standard of $200 \mathrm{MPN} / 100 \mathrm{ml}$ for Class $\mathrm{C}$ waters (DAO, 2008). Presence of fecal coliform indicates contamination of estero with human and animal feces drained directly from toilet pipes and piggeries. Hog-raising causes large quantity of fecal material being washed into the water during high rainfall resulting to increased Coliform count (Olaguer et al., 2010). In developing countries, Escherichia coli (E.coli) was found in hog manure which when used as 
fertilizer can be a vehicle for environmental and domestic animal contamination (Holley et al., 2008). Site 3 had the highest fecal coliform count with the highest BOD reading but lowest DO which did not meet the DENR standards. The result may indicate that the bacteria thriving in the area break down the organic waste under aerobic condition which results to reduced DO. Findings of Lopez et al. (2013) revealed a higher quantity of aerobic coliform in surface water than in sediments in creeks. High microbial activity in the area lowers the $\mathrm{pH}$ of water. This finding is similar to the study of Dragun et al. (2011) on a medium-size stream.

\section{Table 2. Microbial count in three sampling sites.}

\begin{tabular}{lc}
\hline \hline Sampling Site & Fecal coliform (MPN/ 100mL) \\
\hline Site 1 (Brgy. Calabayan) & 4600 \\
Site 2 (Brgy. Lam-an) & 11,000 \\
Site 3 (Brgy. San roque) & $>11,000$ \\
\hline
\end{tabular}

There were more households that drained human and pig excreta in Site 2 than in Site 3, but the quantity of fecal coliform was lower in Site 2. This could be due to the rapid stream velocity in Site 2 which can carry and accumulate the organic waste in Site 3. Downstream of urban rivers of developing countries continuously becomes the endpoint of effluents that poses a negative impact on water quality (Phiri et al., 2005). Household sewage is a primary source of microbial pollution (Dragun et al., 2011). Although the BOD in Site 2 is increasing with decreasing DO, (DENR standards for Class C), its shallow water $(18.3 \mathrm{~cm})$ allows more atmospheric oxygen to dissolve in water compensating the amount of oxygen consumed by bacteria. Continuous fecal contamination can further decrease the DO as more bacteria use oxygen during the breakdown of organic wastes affecting the survival of other aerobic aquatic organisms (Olaguer et al., 2010)

Site 1 had the lowest fecal coliform but the count still exceeded the DENR limit of $200 \mathrm{MPN} / 100 \mathrm{~mL}$. In this less-inhabited area, there were no houses along the water that drained directly human waste but 
occasional human feces were found along the stream banks and a pig was also tethered along the creek. Rain could wash the fecal material into water. Olaguer et al. (2010) associated increase in coliform abundance in the river with high rainfall that carried animal waste by runoffs. The lowest stream velocity $(9.1 \mathrm{~cm} / \mathrm{sec})$ could also result to coliform contamination by concentrating pollutants in the area. In the study of Jha et al. (2010), reduced fish assemblage was due to increased agricultural pollutants that became concentrated in water in sluggish water. In Site 1, the guppy and catfish were the only fishes observed.

The BOD and DO readings meet the DENR standards, however, using the water quality standards of Environmental Protection Administration, BOD that falls within 3 to approximately 4.9 indicates that the stream is lightly polluted (EPA, 2012). Comparing the results of the study of Gorme et al. (2010) in five urban rivers in Metro Manila, Philippines, the BOD loading is far higher than in Carangan Estero which implies that the water is not as polluted as Metro Manila esteros. However, if this water pollution problem continues without sustainable interventions to reduce contamination, water quality can further deteriorate.

Fecal contamination in Carangan Estero may result in infectious diseases that infect aquatic and terrestrial life. Coliform contamination may lead to water-borne diseases causing a health problem in human as these diseases increase morbidity and mortality (Govender et al., 2011). The outbreak of Leptospirosis after a flood in Metro Manila which resulted to human mortality could be attributed to water pollution in esteros (Amilasan et al., 2013). In Nigeria, bacterial quantities of pipe borne water and other natural water supplies have been reported to be unsatisfactory, with coliform counts far exceeding the level recommendation by World Health Organization (W.H.O). The probability of ingesting infective dose of disease causingmicroorganism is very high, considering the fact that water borne pathogens generally have low infective dose (Shittu et al., 2008).

The identification of potential fecal coliform point sources and input locations is necessary to develop management practices to address fecal inputs. In this study, fecal materials were drained directly from toilets and piggeries. Almost all houses built along estero do not 
have septic tanks that can initially store the waste for treatment prior to disposal.

\section{Conclusion and Recommendations}

Water quality is deteriorating downstream along Carangan Estero due to relatively high influx of waste from toilets, kitchen, piggeries, laundry and commercial establishments and indiscriminate dumping of solid waste associated with dense population. Upstream is less polluted but the quarry activity and presence of dam alter other physicochemical parameters below the standards for Class $\mathrm{C}$ waters. Organic pollution is massive midstream but the rapid relative stream velocity maintains other physicochemical parameters within the standards as wastes are carried downstream along the water current. Pollution from upstream is carried downstream. Continuous influx of pollutants is detrimental because of the limited buffering capacity of water. The increasing fecal coliform contamination downstream that exceeds the national limit makes the water not suitable for human consumption and other domestic and recreational purposes. The use of this water may pose a danger to human health. The present condition of Carangan Estero could possibly pose a threat to the water quality in Panguil Bay.

The use of septic tanks among the estero community for toilets, kitchen and piggeries with the support of the local government can reduce organic contamination. Continuous clean-up of estero and monitoring of water quality are essential to evaluate the effects of interventions. Proper solid waste management shall be implemented. Further comprehensive studies are necessary to assess the impact of quarry and dam to aquatic ecosystem upstream. A collaborative and sustainable community extension program shall be delivered to restore the water quality in Carangan Estero.

\section{Acknowledgment}

Authors sincerely thank the Misamis University for funding this study and the Department of Environment and Natural Resources in Ozamiz City for the collaboration. The Office of Misamis University Community Extension Program is also acknowledged for helping in disseminating to the local government and community the goal of this undertaking. 


\section{Literature Cited}

Alipa, J. S., \& Rosauro, R. (2012, February 10). Floods swamp Ozamiz City, other towns, Inquirer News. Retrieved from http://newsinfo.inquirer.net /143383/floods-swamp-ozamiz-cityother-towns

Amilasan, A. T., Ujiie, M., Suzuki, M., Salva, E., Belo, M. C. P., Koizumi, N., ... \& Ariyoshi, K. (2013). Outbreak of Leptospirosis after Flood, the Philippines, 2009. Emerging Infectious Diseases, 18(1), 91-94. doi: 10.3201/eid1801.101892

AWWA (American Water Works Association) Research Foundation. (1993). Bacterial examination of water. Retrieved from http: //fire.biol.wwu.edu/brodham/biol346_S07/labman_week9b.pdf

APHA. (1998). Standard methods for the examination of water and wastewater. (20th Ed.). American Public Health Association, Washington, DC., USA. Retrieved from http://www.umass. edu/tei/mwwp/acrobat/sm9010-40intro.PDF

BASIN. (2007). General information on alkalinity by Shiela Murphy. Retrieved from http://bcn.boulder.co.us/basin/data/BACT/info/ Alk. html

BBSR. (1997). Determination of dissolved oxygen by the Winkler Procedures. Retrieved from http://bats.bios.edu/methods/ chapter6.pdf

Borlongan, I. G., Golez , N. V., \& Lorque, F. (2010). Physicochemical assessment of the Jalaur river system, Iloilo, Philippines. Siliman Journal, 51(1).

Canini, N. D., Metillo, E. B., Azanza, R. V. (2013). Monsooninfluenced phytoplankton community structure in a Philippine mangrove estuary. Tropical Ecology, 54(3), 331-343. 
Crafford, D., \& Oldewage, A. A. (2011). Uptake of selected metals in tissues and organs of Clarias gariepinus (sharptooth catfish) from the Vaal River system-chromium, copper, iron, manganese and zinc. Water S.A., 37 (2), 181-200.

Cunha, D. G. F., Dodds, W. K., \& Calijuri, M. D. C. (2011). Defining nutrient and biochemical oxygen demand baselines for tropical rivers and streams in Sa o Paulo State (Brazil): A comparison between reference and impacted Sites. Environmental Management, 48:945-956. doi: 10.1007/s00267-011-9739-8

Custer, K. W., Burton, G. A. Jr., Coelho, R. S., \& Smith, P. R. (2006). Determining stressor presence in streams receiving urban and agricultural runoff: Development of a benthic in situ toxicity identification evaluation method. Environmental Toxicology and Chemistry, 25 (9), 2299-2305.

Davis, G. A., \& Davis, J. C. (2011). Lower ship creek water quality monitoring as related to petroleum hydrocarbon pollution and fecal Coliform bacteria - Final Report. Retrieved from http://www. arrialaska.org/

Del Mundo, D. M. \& Rebancos, C. (2008). Water quality analysis of Barangay Talisay and Balibago Creeks, Municipality of Calatagan, Batangas Province. Journal of Nature Studies, 7(2): 169-175.

DAO (DENR Administrtive Order). (2008). Water quality guidelines and general effluent standards. Retrieved from http://www.emb. gov.ph/

DENR-EMB. (2010). Initial headways of DENR'S adopt-an-estero program. Retrieved from http://www.emb.gov.ph/adoptestero.html. 
Dragun, Z., Kapetanovic, D., Raspor, B., \& Teskeredz ic, E. (2011). Water quality of medium size watercourse under base flow conditions: The case study of River Sutla in Croatia. AMBIO: A Journal of the Human Environment, 40:391-407. doi: $10.1007 / \mathrm{s} 13280-010-0119-\mathrm{z}$

Dubois, K. D., Lee, D., \& Veizer1, J. (2010). Isotopic constraints on alkalinity, dissolved organic carbon, and atmospheric carbon dioxide fluxes in the Mississippi River. Journal of Geophysical Research, 115. doi:10.1029/2009JG001102

EMB (Environmental Management Bureau). (2005). Executive Summary. Retrieved from http://www.emb.gov.ph/wqms/

EPA (Environmental Protection Agency). (2012). Water Monitoring Assessment. Total alkalinity. Retrieved from http://water.epa.gov /type/ rsl/monitoring/vms510.cfm

Emeka, U. J., Braide, S. A., \& Chindah, A. C. (2009). Impact of abattoir wastes based on some physicochemical parameters on Woji Creek, Port Harcourt, Nigeria. Management of Environmental Quality: An International Journal,20(5), 581591.

Esguerra, N. A., Amistad, F. T., \& Rabena A. R. (2008). Characterizing the environmental effects of the quarrying industry: The case of strategic quarry sites in the Ilocos Region . UNP Research Journal, 12, 28-50. Retrieved from http://www.eisrjc.com/

Fernandez, P. R. Jr. (2009).The sea around the Philippines: Governance and management for a complex coastal ecosystem. Environment, 51(3), 36-51. Retrieved from www.environment magazine.org

Flores, M. J. L., \& Zafaralla, M. T. (2012). Macroinvertebrate composition, diversity and richness in relation to the water quality status of Mananga River, Cebu, Philippines. Philippine Science Letters, 5(2), 103-113. 
Gaillard, J. C., Pangilinan, M. R., Cadag, J. R., \& Le Masson, V. (2008). Living with increasing floods: insights from a rural Philippine community. Disaster Prevention and Management, 17(3), 383-395.

Gilbuena, R. Jr., R., Kawamura, A., Medina, R., Amaguchi, H., Nakagawa, N., \& Bui, D. D. (2013). Environmental impact assessment of structural flood mitigation measures by a rapid impact assessment matrix (RIAM) technique: A case study in Metro Manila, Philippines. Science of the Total Environment, 456, 137-147.

Goel, G., \& Kaur, S. (2012). A study on chemical contamination of water due to household laundry detergents. Journal of Human Ecology-New Delhi, 38(1), 65-69.

Gorme, J. B., Maniquiz, M. C., Song, P., \& Kim, L. H. (2010). The water quality of the Pasig River in the City of Manila, Philippines: Current status, management and future recovery. Environmental Engineering Research, 15(3), 173-179. doi:10.4491/eer.2010.15.3.173

Govender, T., Barnes, J. M, \& Pieper, C. H. (2011). Contribution of water pollution from inadequate sanitation and housing quality to diarrheal disease in low-cost housing settlements of cape town, South Africa. American Journal of Public Health, 101(7), e4-e9.

Hansel, C. G., Nacua, S. S., Seronay, R. A., Gorospe, M. M., Villarino, A. G., Poblete, T.O., ... \& Gay, W. H. C. (2006). Assessing the headwaters of Layawan River: Linkage between the terrestrial and aquatic ecosystems in Mt. Malindang, Misamis Occidental. SeamoSearca. 1-60. 
Holley, R., Walkty, J., Blank, G., Tenuta, M., Ominski, K., Krause, D., \& Ng, L. K. (2008). Examination of Salmonella and Escherichia coli translocation from hog manure to forage, soil, and cattle grazed on the hog manure-treated pasture. Journal of Environmental Quality, 37(6), 2083-92. doi: 10.2134/ jeq2007.0304

HPTM (Hydrologic Project Training Module). (1999). How to measure biochemical oxygen demand. Retrieved from http://www.cwc. gov.in/main/HP/download

HPTM (Hydrologic Project Training Module). (2002). Understanding biochemical oxygen demand test. Retrieved from http://www .cwc.gov. in/main/HP/download

Islam, M. S., Tusher, T. R., Mustafa, M., \& Mahmud, S. (2012). Effects of solid waste and industrial effluents on water quality of Turag River at Konabari industrial area, Gazipur, Bangladesh. Journal of Environmental Science and Natural Resources, 5(2), 213-218. doi:10.3329/jesnr.v5i2.14817

Jha, B. R., Waidbacher, H., Sharma, S., \& Straif, M. (2010). Study of agricultural impacts through fish base variables in different rivers. International Journal of Science and Technology, 7(3), 609-615.

Jimenez, J. U., De Guzman, A. B., Jimenez, C. R., \& Acuña, R. E. (2009). Panguil bay fisheries over the decades: Status and management challenges. Journal of Environment and Aquatic Resource, 1(1), 15-31.

Juahir, H., Zain, S. M., Yusoff, M. K., Hanidza, T. I. T., Armi, A. S. M., Toriman, M. E., \& Mokhtar, M. (2011). Spatial water quality assessment of Langat river basin (Malaysia) using environmental techniques. Environment Monitoring Assessment, 173, 625-641. doi: 10.1007/ s10661-010-1411-x. 
Langhammer, J. (2010). Water quality changes in the Elbe River basin, Czech Republic, in the context of the post-socialist economic transition. GeoJournal, 75(2), 185-198. doi:10.1007/s10708-0099292-7

Linbo, T. L., Baldwin, D. H., McIntyre, J. K., \& Scholz, N. L. (2009). Effects of water hardness, alkalinity, and dissolved organic carbon on the toxicity of copper to the lateral line of the developing fish. Environmental Toxicology and Chemistry, 28 (7), 1455-1461.

López, O. C. F., Duverne, L. B., Mazieres, J. O., \& Salibián, A. (2013). Microbiological pollution of surface water in the uppermiddle basin of the Reconquista river (Argentina): 2010-2011 monitoring. International Journal of Environment and Health, 6(3), 276-289. doi: 10.1504/IJENVH.2013.054087

Mallin, M. A., McAuliffe, J. A., McIver, M. R., Mayes, D., \& Hanson, M. A. (2012). High pollutant removal efficacy of a large constructed wetland leads to receiving stream improvements. Journal of Environmental Quality, 41 (6), 2046-2055. doi: $10.2134 /$ jeq2012.0025

Martinez, F. B., \& Galera, I. C. (2011). Monitoring and evaluation of the water quality of Taal Lake, Talisay, Batangas, Philippines. Academic Research Journal, 1(1), 229-236.

Martinez, F. B., Mijares, M. B. B., \& Galera, I. C. (2011). Assessment of the Water Quality of Mamba River of Mts. Palaypalay/MataasnaGulod, Southern Luzon, Philippines. International Conference on Chemistry and Chemical Process.IPCBEE vol. 10. IACSIT Press, Singapore

Moore, S. K., Trainers, V. L, Mantua, N. J, Parker, M. S., Laws, E. A., Backer, L. C., \& Fleming, L. E. (2010). Impacts of climate variability and future climate changes on harmful algal blooms and human health. Environment and Health, 4 (Suppl 2). doi: $10.1186 / 1476-069 X-7-S 2-S 4$ 
Morgan, A., Royer, T. V., David, M. B., Gentry, L. E. (2006). Relationship among nutrients, chlorophyll- $a$, and dissolved oxygen in agriculture streams in Illinois. Journal of Environmental Quality, 35(4), 1110-1117. doi: 10.2134/jeg 2005.0433.

Naiman, R. J., \& Dudgeon, D. (2011). Global alterations of freshwaters: influences on human and environment well-being. Ecological Research, 26 (5), 865-873. doi:10.1007/s11284-0100693-3

O’Toole, A. C. O., Hanso, K. C., \& Cooke, S. J. (2009). The effects of shoreline recreational angling activities on aquatic and riparian habitat within an urban environment: implications for conservation and management. Environmental Management, 44, 324-334. doi: 10.1007/s00267-009-9299-3

Odeyemi, A. T., Dada, A. C., Akinjogunla, O. J., \& Agunbiade, O. R. (2011). Bacteriological, physicochemical and mineral analysis of water used in abattoirs in Ado-Ekiti, Southwest Nigeria. Journal of Microbiology and Biotechnology Research, 1(2), 14-20.

Olaguer, I. L., Mendoza, S. A. P., Yamamoto, A., \& Pakingking, R. (2010). Seasonal changes and coliform load of Jalaur River, Province of Iloilo, Panay Island, Philippines. Siliman Journal, 51(1), 247-264.

Omuku, P. E., Abugu, H. O., Uduma, K. A. (2012). Evaluation of pH and total dissolved solid of borehole waters in three local government area of Imo state. Journal of International Environmental Application and Science, 7(1), 62-65

Osibanjo, O., Daso, A. P., \& Gbadebo, A. M. (2011). The impact of industries on surface water quality of River Ona and River Alaro in Oluyole Industrial Estate, Ibadan, Nigeria. African Journal of Biotechnology, 10 (4), 696-702. doi: 10.5897/AJB10.1065 
Orozco, G. P., \& Zafaralla, M. T. (2012). Biophysico-chemical and socioeconomic study of two major Manila esteros. Biology Education for Social and Sustainable Development, 161-171. doi: 10.1007/978-94-6091-927-5_17

Partnerships in Environmental Management for the Seas of East Asia (PEMSEA), Department of Environment and Natural Resources (DENR) and Laguna Lake Development Authority (LLDA). (2013). Total pollutant loading study in the Laguna de Bay-Pasig River-Manila Bay Watershed. Retrieved from http://www. pemsea.org / sites/default/files /Total-Pollutant-Loading-StudyLaguna-de-Bay-Pasig-River-Manila-Bay-Watershed.pdf

Phiri, O., Mumba, P., Moyo, B. H. Z., \& Kadewa, W. (2005). Assessment of the impact of industrial effluents on water quality of receiving rivers in urban areas of Malawi. International Journal of Environmental Science and Technology, 2(3), 237-244.

Qian, Q., Parajuli1, B., Fu, Q., Yan, K., Gossage, J. L., \& Ho, T. (2013). Assessment of acid deposition effects on water quality of the upper Rio Grande River section in Texas. Journal of Water Resource and Protection, 5, 792-800.

Rañola, R. A. G., \& Santiago, K. S. (2009). Assessing the Sediment Quality of Estero de Sante Bañez. Philippine Journal of Science, 138 (2), 211-217.

Shittu, O. B., Olaitan, J. O., \& Amusa, T. S. (2008). Physico-chemical and bacteriological analyses of water used for drinking and swimming purposes in Abeokuta, Nigeria. African Journal of Biomedical Research, 11, 285-290.

Sikder, M. T., Kihara, Y., Yasuda, M., Yustiawati, Mihara, Y., Tanaka, S., ... \& Kurasaki, M. (2013). River water pollution in developed and developing countries: Judge and assessment of physicochemical characteristics and selected dissolved metal concentration. CLEAN Soil, Air, Water, 41(1), 60-68. doi: 10.1002/clen.201100320 
Smith, P. J. (2007). Climate change, weak states and the "War on Terrorism' in south and Southeast Asia. Contemporary Southeast Asia, 29(2), 264-285.

Sundberg, C., Yu, D., Whittle, I. F., Kauppi, S., Smars, S., Insam, H., ... \& Jönsson, H. (2013). Effects of $\mathrm{pH}$ and microbial composition on odour in food waste composting. Waste Management, 33(1), 204-211. doi: 10.1016/j.wasman. 2012. 09. 017

Supit, C., \& Ohgushi, K. (2012). Dam construction impacts on stream flow and nutrient transport in Kase River Basin. International Journal of Civil \& Environmental Engineering. 12 (3), 1-5.

Tarkan, A. S. (2010). Effects of streams on drinking water reservoir: An assessment of water quality, physical habitat and some biological features of the streams. Journal of FisheriesSciences.com, 4(1), 8-19. doi: 10.3153/jfscom. 2010002

Teresa, F. B., Romero, Rde M., Casatti, L., \& Sabino, J. (2011). Fish as indicators of disturbance in streams used for snorjkeling activities in a tourist region. Environmental Management, 47(5), 960-968. doi: 10.1007/s00267-011-9641-4

Thirupathaiah, M., Samatha, Ch., \& Sammaiah, C. (2012). Analysis of water quality using physico-chemcial parameters in lower manair reservoir of Karimnagar district, Andhra Pradesh. International Journal of Environmental Sciences, 3(1), 172-180. doi: 10.6088/ijes. 2012030131017

Venkatesharaju, K., Ravikumar, P., Somashekar, R.K., \& Prakash, K.I. (2010). Physico-chemical and bacteriological investigation on the river of Cauvery of Kollegal Stretch in Karnataka. Kathmandu University Journal of Science Engineering and Technology, 6(1), 50-59. doi: 10.3126/kuset.v6i1.3310 